\title{
Pothole structure in the Ala-Penikka PGE Reef, Penikat layered intrusion, Northern Finland
}

\author{
T. A. A. Halkoaho \\ Geological Survey of Finland \\ Corresponding author e-mail: tapio.halkoaho@gtk.fi
}

Summary The Penikat layered intrusion is located in southwest Lapland, Northern Finland. The intrusion contains two main units: the marginal series and layered series, the layered series being further divided into five megacyclic units (MCUs). The intrusion contains three major PGE-enriched zones. The middle one, termed Ala-Penikka PGE reef contains a large PGE enriched pothole structure.

\section{Introduction and background to current research}

The $2.44 \mathrm{Ga}$ Penikat layered intrusion is $23 \mathrm{~km}$ long and 1.5 to $3.5 \mathrm{~km}$ wide and its footwall rocks consist of late Archaean/early Palaeoproterozoic granitoids. The hanging wall rocks, younger than the intrusion, are either tholeiitic volcanic rocks, subvolcanic sills or in places a polymictic conglomerate. The intrusion forms five westward-dipping blocks, the borders of which are bounded by roughly east-west-trending faults. These blocks are designated as the Ala-Penikka, Keski-Penikka, Yli-Penikka, Kilkka and Sompujärvi. The intrusion is divided into two principal units: the marginal series and the layered series. The layered series has been divided into megacyclic units (MCUs) I - V (Fig. 1) (Alapieti and Lahtinen, 1986, Alapieti et al., 1990, Halkoaho, 1993, Halkoaho et al., 2005 and Maier et al., 2018). These are interpreted as being attributable to repeated influxes of new magma into the Penikat magma chamber (Alapieti and Lahtinen, 1986). The parental magmas are thought to be siliceous high-Mg basalts in nature, usually classified into high-Cr (MCUs I-III) and low-Cr (MCUs IV-V) types (Alapieti et al., 1990 and Maier et al, 2018).

The Penikat layered intrusion contains three major PGE-enriched zones: the Sompujärvi (SJ), Ala-Penikka (AP) and Paasivaara (PV) PGE Reefs. The SJ Reef is located at the boundary between MCUs III and IV, 500 to $1000 \mathrm{~m}$ above the base of the Penikat layered intrusion. The AP Reef is located 250-450 m above the SJ Reef in the lower part of MCU IV, and the PV Reef about 700-1000 $\mathrm{m}$ above this, in the transition zone between MCUs IV and V (Fig. 1). These PGE reefs have previously been described by Alapieti and Lahtinen (1986, 2002), Halkoaho (1993), Halkoaho et al. (1990ab, 2005), Huhtelin et al. (1990), Törmänen and Alapieti (1996), Kaukonen et al. (2004) and Maier et al. (2018).

\section{Results}

The PGE mineralization referred to as the AP Reef is located 250-450 m above the base of MCU IV. It is known in broad outline for almost the entire $23 \mathrm{~km}$ length of the intrusion (Fig. 1). (Halkoaho et al., 1990b, Halkoaho, 1993). The AP Reef is usually 20 to $40 \mathrm{~cm}$ thick, but at the site of the pothole structure PGEs are concentrated over a wider zone, so that the mineralized rocks attain a vertical thickness of almost $20 \mathrm{~m}$. The AP Reef is situated at the border between plagioclase-augite-bronzite adcumulate and a $3-30 \mathrm{~cm}$ thick poikilitic plagioclase mesocumulate. The AP Reef, with highly variable PGE values, has base metal sulphide disseminations closely associated with it (Fig. 2) (Halkoaho et al., 1990b, Halkoaho et al., 2005). 


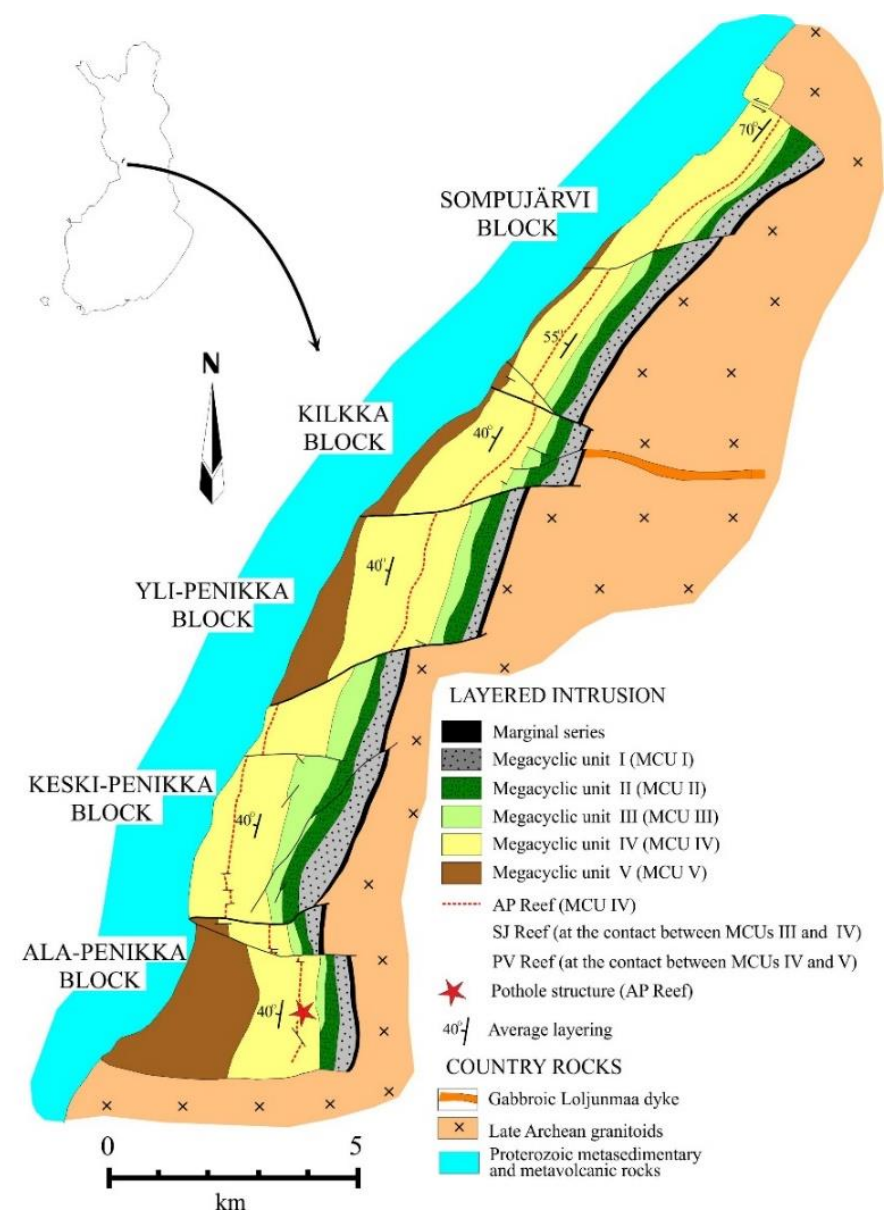

Figure 1. Generalized geological map of the Penikat layered intrusion showing the locations of the megacyclic units (MCU) and PGE reefs. Modified after Alapieti et al. (1990) and Halkoaho et al. (2005).

The pothole structure of the AP Reef is about $300 \mathrm{~m}$ long and $100 \mathrm{~m}$ deep and interrupts the underlying cumulates. This structure forms three separate parts on the present erosional surface, the southernmost one representing the shallowest section of the original structure whereas the northernmost one is the deepest. The cumulus stratigraphy greatly resembles that of the normal AP Reef, but the vertical thicknesses of the layers are distinctly greater. The poikilitic plagioclase mesocumulate is now 2 to $20 \mathrm{~m}$ thick, whereas outside the structure its thickness is only 3 to $30 \mathrm{~cm}$ and the plagioclase-bronzite mesocumulate overlying this plagioclase mesocumulate is now $50 \mathrm{~m}$ thick, whereas it is elsewhere only about $13 \mathrm{~m}$ thick. The pothole structure also features large amounts of gabbronoritic pegmatoids (Halkoaho et al., 2005, Maier et al., 2018) (Fig. 2).

\subsection{Formation of the AP PGE Reef}

It is proposed that the older residual magma became intermixed with the new megacyclic unit IV magma pulse and formed a volatile-rich hybrid magma. This hybrid magma settled to the base of the magma chamber. The PGEs are derived chiefly from the residual magma and to some extent from the fourth magma pulse. The AP Reef formed from an upward-migrating volatile and chalcophile element enriched intercumulus melt trapped below an approximately 10 to $20 \mathrm{~m}$ thick plagioclase-bronzite mesocumulate layer. The partial pressure of oxygen in the fluid phase of the intercumulus melt gradually increased. When intercumulus titanomagnetite began to crystallize, this reduced the solubility of sulphur and triggered the 
formation of a sulphide melt (cf. Shima and Naldrett, 1975), leading to collection of the PGEbearing complexes (Halkoaho et al., 1990b, Halkoaho, 1993).

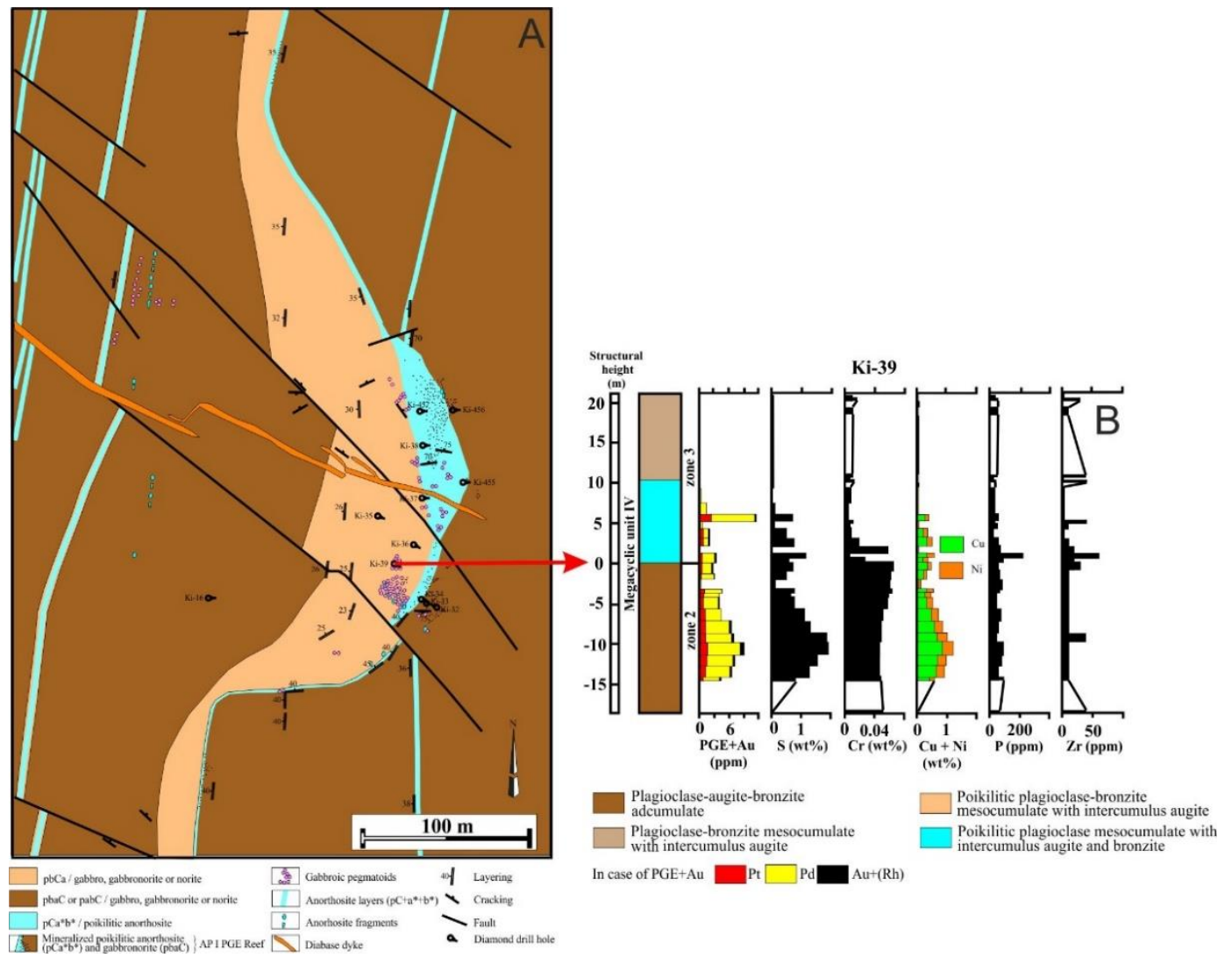

Figure 2. A. Geological map of the pothole area of the AP Reef. B. Stratigraphic sequence of the AP Reef in the pothole structure showing variations in $\mathrm{Pt}+\mathrm{Pd}+\mathrm{Au}, \mathrm{S}, \mathrm{Cr}, \mathrm{Cu}+\mathrm{Ni}, \mathrm{P}$ and $\mathrm{Zr}$. Modified after Halkoaho et al. (1990b), Halkoaho (1993), Alapieti and Lahtinen (2002) and Halkoaho et al. (2005).

Halkoaho et al. (1990b) suggest that the large pothole structure (Fig. 2) has developed as the result of a disturbance in the magma chamber causing the unconsolidated cumulate layers to collapse. The currents of the convection cells in the magma of MCU IV then reworked the structure and smoothed it down, resulting in the formation of a regular channel-like structure. On the other hand, Ballhaus et al. (1988) and Stumpfl and Ballhaus (1986) came to the conclusion that the potholes of the Merensky Reef are primary disturbances and were formed where high concentrations of volatiles locally suppressed the liquidus temperature of plagioclase so that no footwall anorthosite cumulates were formed. Large amounts of discontinous gabbronoritic pegmatoids are also encountered in the area of the pothole structure, so that one possibility is that high volatile activity may also have interfered with the normal crystallization process there (Halkoaho et al., 1990b). Buntin et al. (1985) postulate that the potholes of the Merensky Reef represent scars of late magmatic fumarole activity. Boudreau (1991) also notes that the potholes show morphological similarities to the sedimentary features known as pockmarks and suggests an origin of the same kind for potholes in layered intrusions, i.e. an escape of overpressured gas from underlying sediments and cumulates, respectively. Halkoaho (1993) suggest that the extensive pothole structure occurring in the AP Reef may thus be an outlet for fluids being squeezed out of the crystallizing magma chamber from below. The poikilitic anorthosite of the pothole structure and the plagioclase-augite-bronzite adcumulate 
below it contain PGE-bearing gabbronoritic pegmatites, and there are gabbronoritic pegmatites perpendicular to the layering together with anorthositic fragments about $200 \mathrm{~m}$ above the poikilitic anorthosite (Fig. 2A).

\section{Future prospects}

The large pothole structure in the AP PGE Reef is a remarkable feature as far as ore potential is concerned. The question arises whether pothole is unique in the Penikat layered intrusion or whether there could be more potholes? Also, the formation of the pothole remains unclear and requires further research.

\section{References:}

Alapieti TT, Lahtinen JJ (1986) Stratigraphy, petrology, and platinum-group element mineralization of the early Proterozoic Penikat layered intrusion, Northern Finland. Econ Geol 81:1126-1136.

Alapieti TT, Lahtinen JJ (2002) Platinum-group element mineralization in layered intrusions of Northern Finland and the Kola Peninsula, Russia. Geology, Geochemistry, Mineralogy and Mineral Beneficiation of Platinum-group Elements. In: Cabri LJ (ed) Special Volume 54, Canadian Institute of Mining, Metallurgy and Petroleum, pp 507-546.

Alapieti TT, Filén BA, Lahtinen JJ et al (1990) Early Proterozoic layered intrusions in the northeastern part of the Fennoscandian shield. Mineral Petrol 42:1-22.

Ballhaus CG, Cornelius M, Stumpfl EF (1988) The Upper Critical Zone of the Bushveld Complex and the origin of Merensky-type ores -- a discussion. Econ Geol 83:1082-1085.

Boudreau AE (1991) Fluid overpressure in layered intrusions and the formation of potholes. In: Barnes SJ (ed) IAGOD Comission on Ore Deposits in Mafic and Ultramafic Rocks $6^{\text {th }}$ International Platinum Symposium Program and Abstracts, Perth, Western Australia, pp 11-12.

Buntin TJ, Grandstaff DE, Ulmer GC et al (1985) A pilot study of geochemical and redox relationships between potholes and adjacent normal Merensky Reef of the Bushveld Complex. Econ Geol 80:975-987.

Halkoaho T (1993) The Sompujärvi and Ala-Penikka PGE Reefs in the Penikat Layered Intrusion, northern Finland: implications for PGE reef-forming prosesses. Acta Universitatis Ouluensis. Series A, Scientiae Rerum Naturalium 249, 122 pp.

Halkoaho T, Alapieti T, Huhtelin T (2005) The Sompujärvi, Ala-Penikka and Paasivaara PGE Reefs in the Penikat Layered Intrusion, Northern Finland. In: Alapieti TT, Kärki AJ (eds) $10^{\text {th }}$ International Platinum Symposium, Field Trip Guidebook Early Palaeoproterozoic (2.5-2.4) Tornio-Näränkävaara Layered Intrusion Belt and Related Chrome and Platinum-Group Element Mineralization, Northern Finland, Geol. Surv. Finland, Guide 51a, pp 33-76.

Halkoaho TAA, Alapieti TT, Lahtinen JJ (1990a). The Sompujärvi PGE Reef in the Penikat layered intrusion, Northern Finland. Mineral Petrol 42:39-55.

Halkoaho TAA, Alapieti TT, Lahtinen JJ et al (1990b) The Ala-Penikka PGE Reefs in the Penikat layered intrusion, Northern Finland. Mineral Petrol 42:23-38.

Huhtelin TA, Alapieti TT, Lahtinen JJ (1990) The Paasivaara PGE Reef in the Penikat layered intrusion, Northern Finland. Mineral Petrol 42:57-70.

Kaukonen RJ, Törmänen TO, Alapieti T (2004) Platinum-group mineralogy of the silicate type PGE mineralization in the Penikat layered intrusion, Northern Finland. 32nd International Geological Congress, Florence. Scientific Sessions: abstracts (part 2):1269.

Maier WD, Halkoaho T, Huhma H et al (2018) The Penikat intrusion, Finland: Geochemistry, Geochronology, and Origin of Platinum-Palladium Reefs. J Petrol 59: 967-1006.

Shima H, Naldrett AJ (1975) Solubility of sulfur in an ultramafic melt and the relevance of the system Fe-S-O. Econ Geol 70:960-967.

Stumpfl EF, Ballhaus CG (1986) Stratiform platinum deposits: new data and concepts. Fortschr. Mineralogie, 64: 205-214.

Törmänen T, Alapieti T (1996) Platinum-group mineralogy of the Penikat layered intrusion, Finland. In IGCP project 336 Symposium in Rovaniemi, Finland, August 21-23, 1996: program and abstracts. Turun yliopiston geologian ja mineralogian osaston julkaisuja 38:83. 